\title{
Determination Specific Emission Factor From Industrial Sector For Estimating Carbon Footprint And Mapping In Sumenep District-East Java
}

\author{
Qorry Nugrahayu, Rachmat Boedisantoso, Joni Hermana
}

\begin{abstract}
The value of carbon footprint of industrial sector is 1692,60 ton $\mathrm{CO}_{2} /$ year. The $\mathrm{SEF}$ of industrial sector are 0,229 ton $\mathrm{CO}_{2}$ /year.ton production for food industry, 0,039 ton $\mathrm{CO}_{2}$ /year.unit for metal industry (keris) and 0,00258 ton $\mathrm{CO}_{2}$ /year.unit for mineral products non metal industry (rooftile). In environmental aspect, the best scenario for industrial sector is scenario 1 because it can decrease karbon emission $47,7 \%$ than existent $\mathrm{CO}_{2}$ emission. In legal aspect, the government of Sumenep district should has regulation about using LPG (Liquid Petroleum Gas) for industrial sector which refers to "President Regulation of the Republic of Indonesia No. 104 Year 2007" about on provision, distribution and pricing of Liquefied Petroleum Gas $3 \mathrm{~kg}$ ”
\end{abstract}

KeyWords---Industry, Carbon Footprint, $\mathrm{CO}_{2}$ emission, Specific Emission Factor, Sumenep District

\section{Introduction}

One of sources of air pollution from industrial sector is production process emission (from used fuel). Carbon emission is the biggest contributor of Greenhouse Gases. Even today estimated $\mathrm{CO} 2$ concentration in atmosphere is the most dominant of all greenhouse gases [1]. In line with that, produced $\mathrm{CO}_{2}$ emission from activity of fossil fuel combustion is quite high, ranging from $10-12 \%$ [2]. Based on the problems, Indonesian goverment issued a regulation in "President Regulation No. 71/2011 about implementation of the National Greenhouse Gas Inventory". It require that each provincial and district government to do inventory of greenhouse gas which one of them is $\mathrm{CO}_{2}$ emission. The result of inventory should be reported every year by district government to provincial government, provincial government to national governement and national government to the secretariat of the UNFCCC (United Nations Framework Convention on Climate Change). Therefore, this study will be carried out calculation to

Qorry Nugrahayu

Environmental Engineering - Universitas Islam Indonesia Indonesia estimate the carbon footprint from industrial sector in Sumenep District. Based on spatial plans map of East Java, Sumenep District is area with the function of regional development of agriculture/horticulture. The parameter in this study is $\mathrm{CO}_{2}$ emission and the calculated $\mathrm{CO}_{2}$ emission is primary emission.

\section{Method}

\section{A. Data Collection}

- Number of fuel consumption and production capacity in the industrial sector.

- Number of industry for each type of industry

- Government regulation

\section{B. Aspect of Study}

- Technical Aspect

This aspect explains about calculation from the obtained data. It begins from calculating the carbon footprint $\left(\mathrm{CO}_{2}\right.$ emission) using IPCC guidlines Tier 2. Then calculating specific emission factor and mapping the estimated carbon footprint $\left(\mathrm{CO}_{2}\right.$ emission). The purpose of calculating SEF is helping other regions with the function of regional development of agriculture/horticulture (the same spatial plans) that do not have complete data for doing inventory of greenhaouse gases. Mapping the carbon footprint can be use to arrange strategic measure to decrease $\mathrm{CO}_{2}$ emission that has spread. The used formula to estimate carbon footprint is

$$
\text { Emisi } \mathrm{CO}_{2}=\sum \mathrm{FC} \text { x CEF x NCV }
$$

$\sum \mathrm{FC}=$ Total Consumption Fuel $(\mathrm{Gg})$

$\mathrm{CEF}=$ Carbon Emission Factor of $\mathrm{CO}_{2}$ Emission (Based on the type of fuel) $(\mathrm{Kg} / \mathrm{TJ})$

$\mathrm{NCV}=$ Net Calorific Volume (Based on the type of fuel) $(\mathrm{TJ} / \mathrm{Gg})$

- Aspek Lingkungan

This aspect consists of some scenarios. The purpose of determination of scenarios is as attempt or alternative measures to reduce $\mathrm{CO}_{2}$ emission in Sumenep District based on existing $\mathrm{CO}_{2}$ emission. After calculating every scenario, persentage of $\mathrm{CO}_{2}$ emission reduction will be known. Persentage of 
$\mathrm{CO}_{2}$ emission reduction can be as consideration for alternative election which can be applied in Sumenep District. There are 2 scenarios in environmental aspect, they are:

Scenario 1 : How much $\mathrm{CO}_{2}$ emission if the entire of food industries that use firewood as fuel of the production process is changed using LPG

Scenario 2 : How much $\mathrm{CO}_{2}$ emission if half of food industries that use firewood as fuel of the production process is changed using LPG

- Legal Aspect

Legal aspect explains about legal/regulation in Sumenep District which regulating industrial sector. This study gives the better regulatory recommendations related to generated $\mathrm{CO}_{2}$ emission from industrial sector.

\section{Result}

After doing survey, there are 3 types of industry that produce the primary emission in Sumenep District. They are food industry, metal industry (keris) and mineral products non metal (roof tile). Some types of industry use electricity for production process (producing secondary emission). Used fuel in production process for food industry in the manufacture of coconut oil and palm sugar is firewood while others use LPG. Used fuel for mineral product non metal industry for the manufacture of roof tile using straw, coconut fiber, husk and coconut leaves.

1. Technical Aspect

- Carbon Footprint Calculation

Carbon footprint is calculated based on fuel consumption for production process in industrial sector. It is calculated using (1). The emission factor for $\mathrm{CO}_{2}$ and $\mathrm{NCV}$ each type of fuel can be seen in Table 1

EMISSION FACTOR $\mathrm{CO}_{2}$ AND NCV OF FUEL

\begin{tabular}{|c|c|c|}
\hline Type of Fuel & CEF (Kg/TJ) & NCV (TJ/Gg) \\
\hline LPG & $63100^{[3]}$ & $47.4^{[4]}$ \\
\hline Kayu Bakar & $112000^{[3]}$ & $15^{[4]}$ \\
\hline Arang & $112000^{[3]}$ & $30^{[4]}$ \\
\hline Serabut Kelapa & $100000^{[3]}$ & $9.8^{[4]}$ \\
\hline Jerami & $100000^{[3]}$ & $15.2^{[4]}$ \\
\hline Sekam & $100000^{[3]}$ & $14.4^{[4]}$ \\
\hline $\begin{array}{c}\text { Biomassa Lain } \\
\text { coconut leaf) }\end{array}$ & $100000^{[3]}$ & $11^{[4]}$ \\
\hline \multicolumn{2}{|c|}{} & $\begin{array}{r}\text { Source: }^{[3]} \text { IPCC, } 2006 \\
{ }^{[4]} \text { IPCC, } 1996\end{array}$
\end{tabular}

After calculating the carbon footprint using [1] then value of $\mathrm{CO}_{2}$ emission from sector industry in Sumenep District is obtained.
TABLE II.

CARBON FOOTPRINT OF INDUSTRIAL SECTOR

\begin{tabular}{|c|c|c|c|}
\hline \multirow{2}{*}{$\begin{array}{c}\text { Carbon Footprint } \\
\text { (Ton CO2/year) }\end{array}$} & Food & $\begin{array}{c}\text { Industrial Type } \\
\text { Metal } \\
\text { (Keris) }\end{array}$ & $\begin{array}{c}\text { Mineral } \\
\text { Products } \\
\text { non Metal } \\
\text { (Roof Tile) }\end{array}$ \\
\hline $\mathrm{CO}_{2}$ emission & 1107.05 & 115.25 & 470.3 \\
\hline
\end{tabular}

The higest value of $\mathrm{CO}_{2}$ emission is food industry because the amount of food industry is the higest than other industries, moreover mostly using forewoof

- $\quad$ Specific Emission Factor calculation

SFE calculations is obtained after calculating the carbon footprint. The carbon footprint is devided by activity data. The used activity data is production capacity.

TABLE III. SPECIFIC EMISSION FACTOR OF INDUSTRIAL SECTOR

\begin{tabular}{|l|c|c|c|}
\hline \multirow{2}{*}{} & \multicolumn{3}{|c|}{ Industrial Type } \\
\cline { 2 - 4 } & Food & $\begin{array}{c}\text { Basic Metal } \\
\text { (Keris) }\end{array}$ & $\begin{array}{c}\text { Non-Metal } \\
\text { Mineral } \\
\text { Products (Roof } \\
\text { Tile) }\end{array}$ \\
\hline $\begin{array}{l}\text { Specific } \\
\text { Emission } \\
\text { Factor }\end{array}$ & $\begin{array}{c}0.229 \text { (ton } \\
\mathrm{CO}_{2} / \text { year.ton } \\
\text { of } \\
\text { production) }\end{array}$ & $\begin{array}{c}0.039 \text { (ton } \\
\mathrm{CO}_{2} / \text { year.unit) }\end{array}$ & $\begin{array}{c}0.00258 \text { (ton } \\
\mathrm{CO}_{2} / \text { year.unit) }\end{array}$ \\
\hline
\end{tabular}

As the production capacity for food industry is 4825.33 ton/year while for basic metal industry (keris) and non-metal mineral product (roof tile) are 1440 unit/tahun dan 182.500 unit/year.

\section{- $\quad$ Mapping}

Mapping is drawn for every subdistrict in Sumenep district based on industrial deployment.

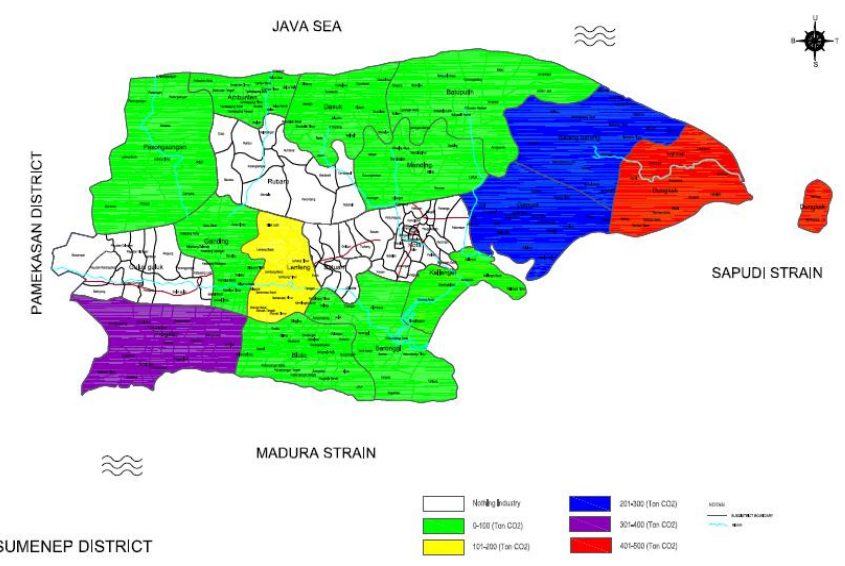

Figure 1. Mapping of $\mathrm{CO}_{2}$ Emission Every Subdistrict 
TABLE IV CARBON FOOTPRINT MAPPING OF INDUSTRIAL SECTOR

\begin{tabular}{|c|c|c|}
\hline $\begin{array}{c}\text { Name of } \\
\text { Subdistrict }\end{array}$ & Color & $\begin{array}{c}\mathbf{C O}_{2} \\
\text { Emission } \\
\text { (ton } \\
\mathbf{C O}_{2} / \text { year }\end{array}$ \\
\hline Dungkek & Red & $401-500$ \\
\hline Batang-batang & Blue & $201-300$ \\
\hline Gapura & Blue & $201-300$ \\
\hline Lenteng & Yellow & $101-200$ \\
\hline Bluto & Green & $0-100$ \\
\hline Pragaan & Gray & $0-100$ \\
\hline Batuan & Green & $0-100$ \\
\hline Batu Putih & Green & $0-100$ \\
\hline Manding & Green & $0-100$ \\
\hline Dasuk & Green & $0-100$ \\
\hline Kalianget & Green & $0-100$ \\
\hline Ambunten & Green & $0-100$ \\
\hline Pasongsongan & Green & $0-100$ \\
\hline Saronggi & Green & $0-100$ \\
\hline
\end{tabular}

Mapping results indicate that the subdistrict having the highest $\mathrm{CO}_{2}$ emission is Dungkek. It is because there are many food industries using firewood as fuel of production process and the non metal mineral products (roof tile) industries use some biomassa fuel such us palm leaves, coconut fiber, straw and husk.

\section{Aspek Lingkungan}

The calculation result of several determinated scenarios can be seen in Table $\mathrm{V}$

TABLE V. PRESENTAge OF REDUCTION

\begin{tabular}{|l|c|c|}
\hline \multirow{2}{*}{} & \multicolumn{2}{|c|}{ Scenarios } \\
\cline { 2 - 3 } & $\boldsymbol{I}$ & II \\
\hline $\begin{array}{l}\text { Presentage of } \\
\text { reduction (\%) }\end{array}$ & 47.4 & 24.7 \\
\hline
\end{tabular}

The higest reduction persentage of $\mathrm{CO}_{2}$ emission is skenario $1(47 \%)$. For further it can be alternative measure to decrease $\mathrm{CO}_{2}$ emission in Sumenep District for indutrial sector.

3. Legal Aspect

The function of legal aspect is supporting the implementation of selected scenario. at this time there is no regulation in Sumenep District regarding the obigation to use LPG for fuel of small industry and prohibiting to use of biomass fuel. Sumenep Government is expected having regulation by reffering to "President Regulation of the Republic of Indonesia
No. 104 Year 2007" about on provision, distribution and pricing of Liquefied Petroleum Gas $3 \mathrm{~kg}$ " as reference material. Then arrange the socialization about the regulation to Sumenep people in order they can understand and obey it.

\section{Conclusion}

Based on this study, it can be conclude that usage of biomass fuels such as firewood, rice husk, straw and others can produce high $\mathrm{CO}_{2}$ emission compared to the usage of LPG fuel. That is because the emission factor of biomass fuels is high and the net calorific volume is small, inversely proportional to LPG which has the small emission factor and high net calorific volume value.

\section{Acknowledgment}

Author thanks to the LPPM (Institut for Reasearch and Community Service) ITS (Institut Teknologi Sepuluh Nopember) that have been willing to fund this PUPT 2014. Then author would like to thank the Universitas Islam Indonesia who have been offered an opportunity for author to follow the $4^{\text {th }}$ International Conference on Advanced Science and Environmental Technology.

\section{References}

[1] Setiawan, R. Y, "Kajian Carbon Footprint dari kegiatan industri di Kota Surabaya” Environmental Engineering ITS, 2011.

[2] Santoso, A. D., Darmawan, R., A., Santoso, J., P, "Mikro Alga Untuk Penyerapan Emisi $\mathrm{CO}_{2}$ dan Pengolahan Limbah Cair di Lokasi Industri” Pusat Teknologi Lingkungan, Badan Pengkajian dan Penyerapan Teknologi (BPPT), 2011

[3] Intergovernmental Panel on Climate Change (IPCC), "Guidelines for National Greenhouse Gas Inventories", 2006

[4] Intergovernmental Panel on Climate Change (IPCC), "Guidelines for National Greenhouse Gas Inventories", 1996

About Author (s)

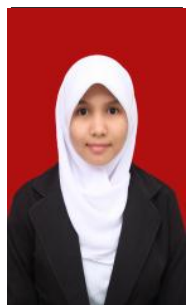

Qorry Nugrahayu is a lecturer at Environmental Engineering Department of Universitas Islam Indonesia. Graduated bachelor and master degree from Institut Teknologi Sepuluh Nopember. Interested topic study is air pollution (greenhouse gases emission) 